\title{
Does fire determine distinct floristic composition of two Cerrado savanna communities on different substrates?
}

\author{
Eddie Lenza1, , Ana Clara Abadia², Hélio Menegat², Nadjarriny W. Lúcio², Leonardo Maracahipes-Santos ${ }^{3}$, \\ Henrique A. Mews ${ }^{4}$, Josias 0. dos Santos ${ }^{2}$ and Jhany Martins ${ }^{2}$
}

Received: June 9, 2016

Accepted: March 23, 2017

\begin{abstract}
We surveyed two savanna sites, one on flat terrain with deep soil (DS), and the other on hilly terrain with rocky outcrops and shallow soil (RS), before and after an accidental fire. We found that the fire did not cause any significant changes in the species composition or diversity of either community, and did not result in floristic homogenization. However, we did record a reduction in the density of plants and in basal area in the DS savanna in comparison with the RS savanna, as well as a higher rate of basal sprouting, which indicates a trade-off between mortality and sprouting. We conclude that, whereas post-fire changes in vegetation structure were more pronounced in the DS savanna than in the RS, the difference in the underlying substrate did not have a direct influence on the post-fire composition of woody species. The greater grass biomass found in the DS savanna in comparison with the RS savanna appears to have been the principal modulator of the severity of the fires in the two phytophysionogmies, and accounts for the distinct responses to fire we observed in the two woody communities.
\end{abstract}

Keywords: diversity, fire, fuel, savanna, species composition

\section{Introduction}

Savanna-like ecosystems are widely distributed in the tropics, where they can be found in an ample variety of habitats, ranging from flat plains to mountainous terrain, on a diversity of soil types (Collinson 1988; Young \& Solbrig 1993; Mews et al. 2014). The vegetation of tropical savannas is physiognomically very variable, but is characterized by the coexistence of well-established arboreal and grassy strata. Fire is one of the principal ecological drivers of savannas worldwide (Bond \& Keeley 2005), modulating the coexistence of grassland, savanna and forest formations (D'odorico et al. 2006; Geiger et al. 2011), and shaping the different physiognomies. Through its interaction with the climate and soil, fire can modify the basal area of woody species in savanna habitats, with profound implications for carbon storage (Lehmann et al. 2014). Fire is thus the agent that determines the coexistence between trees and grasses (D'odorico et al. 2006) and influences the occurrence of plants with distinct functional traits in terms of their resistance to fire (Dantas et al. 2013), such as thick bark (Dantas \& Pausas 2013) and basal sprouting capacity (Hoffmann 1998).

In Brazil, most of savanna is known as the Cerrado, which originally covered an area of more than two million square kilometers. The savanna formations of the Cerrado are found primarily on deep soils (mainly Oxisols) on relatively flat terrain (Reatto et al. 2008). However, around $7 \%$ of the

\footnotetext{
${ }^{1}$ Curso de Ciências Biológicas, Universidade do Estado de Mato Grosso, P.O. Box 08, 78690-000, Nova Xavantina, MT, Brazil

${ }^{2}$ Programa de Pós-graduação em Ecologia e Conservação, Universidade do Estado de Mato Grosso, P.O. Box 08, 78690-000, Nova Xavantina, MT, Brazil

${ }^{3}$ Instituto de Pesquisa Ambiental da Amazônia, Rua Horizontina 104, 78640-000, Canarana, MT, Brazil

${ }^{4}$ Centro de Ciências Biológicas e da Natureza, Universidade Federal do Acre, P.O. Box 500, 69920-900, Rio Branco, AC, Brazil

* Corresponding author: eddielenza@yahoo.com.br
} 
Cerrado is made up of savannas growing on shallow soils associated with rocky outcrops (Entisols), generally on steep, hilly relief. Recent evidence indicates that these two types of savanna are highly similar in their woody species composition, but diverge considerably in the density of their populations (Mews et al. 2014). These savannas are also quite distinct in their grassy cover and the amount of biomass, which is the primary source of combustible material, and is reduced in savanna on rocky soils. A greater grass biomass intensifies the severity of fires (Miranda et al. 1993; 2002; Felfili et al. 2000), which reduce tree density (Medeiros \& Miranda 2005; Gomes et al. 2014), the biomass of the vegetation (Hoffmann 1996), and recruitment rates (Hoffmann 1996; 1998). Fire also supports the selective exclusion of the more sensitive plant species (Hoffmann \& Moreira 2002; Gomes et al. 2014), leading to the simplification of species composition and, consequently, the reduction of species diversity over time (Libano \& Felfili 2006). More frequent fires increasingly damage the woody vegetation of savannas worldwide (Lehmann et al. 2014), including the Brazilian Cerrado (Moreira 2000), making the vegetation more open. Given the ongoing increase in the frequency of fires (Ramos-Neto \& Pivello 2000; Pivello 2011) and the progressive conversion of Cerrado habitats into farmland (Sano et al. 2010), especially on areas of flatter terrain with deep soils (Klink \& Machado 2005), it is increasingly important to understand the relationship between fire and these different types of substrate.

In the present study, we surveyed two physiognomies of the Cerrado sensu stricto (see Ribeiro \& Walter 2008), located on different types of substrate before and after an accidental fire. This category (Cerrado sensu stricto) is the predominant type of vegetation ( $70 \%$ of the total area) found in the Brazilian savanna, whose structure is characterized by a mixture of shrubs and small trees with twisted branches, and a herbaceous layer dominated by grasses (Ribeiro \& Walter 2008). The Cerrado sensu stricto is subdivided into four typical savanna physiognomies differentiated by the structure of the vegetation (mainly in the density and height of the shrub-tree layer) (Ribeiro \& Walter 2008) and the properties of the soil, in particular the fertility, depth and moisture (Ruggiero et al. 2002; Carvalho et al. 2014). These physiognomies are also maintained or modified by fire (Moreira 2000). Our objective was to understand the effects of the fire on floristic composition, species diversity, and the density and sprouting patterns of the woody plants. In particular, we tested the prediction that fire results in greater changes in species composition and diversity, as well as a greater reduction in plant density and basal area in the savanna on deep soil on flat terrain (DS) in comparison with the savanna on hilly, rocky soil (RS). This prediction was supported by the fact that grasses form a well-defined and continuous stratum in the DS savanna, providing more fuel for fires in comparison with the RS savanna, where the grassy layer is discontinuous and occupies the gaps between the rocks (Oliveira-Filho \& Ratter 2002; Ribeiro \& Walter 2008). We discuss the implications of our findings for the conservation of the two physiognomies and for the regional diversity of plant species.

\section{Materials and methods}

\section{Study area}

We conducted this study on a private property in the municipality of Nova Xavantina, in the state of Mato Grosso, Brazil (Fig. 1A, B). We sampled one savanna site on flat terrain with deep soil (DS) (14\% $\left.48^{\prime} \mathrm{S}, 52^{\circ} 34^{\prime} \mathrm{W}\right)$ and a second site on hilly terrain with rocky outcrops and shallow soil (RS) $\left(14^{\circ} 48^{\prime} \mathrm{S}, 52^{\circ} 35^{\prime} \mathrm{W}\right)$ approximately $1.5 \mathrm{~km}$ away. The region's climate is of Köppen's Aw type, with well-defined dry (May-September) and rainy (October-March) seasons (Silva et al. 2008). According to data from the Meteorological Station located in Nova Xavantina-MT (9th District of Meteorology, Ministry of Agriculture, INMET 83319-MT), the average annual rainfall calculated over a 15 -year period was approximately $1,536 \mathrm{~mm}$, with annual mean around 25 ${ }^{\circ} \mathrm{C}$ (Marimon \& Felfili 2006). According to the landowner, the two studied areas has been accidentally burned every two years since 2004, that is, in 2006, 2008, 2010, 2012, and 2014. The DS savanna is located at an altitude of 440 $\mathrm{m}$ on quartzitic sandy soils, while the RS savanna is located at an altitude of $340 \mathrm{~m}$, on quartzitic soils.

\section{Data collection}

At each site, we established 10 plots of $20 \times 50 \mathrm{~m}$, with a total area of one hectare (Felfili et al. 2005) and a minimum distance of $50 \mathrm{~m}$ between plots. Each plot was subdivided into 10 subplots of $10 \mathrm{~m} \times 10 \mathrm{~m}$ (Fig. 1C). We identified and measured the stem diameter of all live woody plants (including lianas and arborescent monocotyledons), with a base diameter, measured at $30 \mathrm{~cm}$ from the soil $\left(\mathrm{Db}_{30 \mathrm{~cm}}\right) \geq$ $5 \mathrm{~cm}$. When possible plants were identified in the field, but sampled collections were compared with vouchers in the NX herbarium or sent to taxonomists for confirmation. We used the APG IV (2016) system of families and the species nomenclature was confirmed accessing the Brazilian Flora Checklist (Lista de Espécies da Flora do Brasil 2015).

The first vegetation inventory was in August 2014, one month before the occurrence of a fire, and again in May 2015, eight months after the fire. In October 2014, one month after the fire, we surveyed the two sites and discovered that all the DS plots had been burned, while seven RS subplots (7\% of total) were unburned (four subplots in plot four and three in subplot seven). During these inventories, we included all new plants that had reached the minimum size for inclusion in the sample (treated as recruits). Plants that were considered to be alive during 


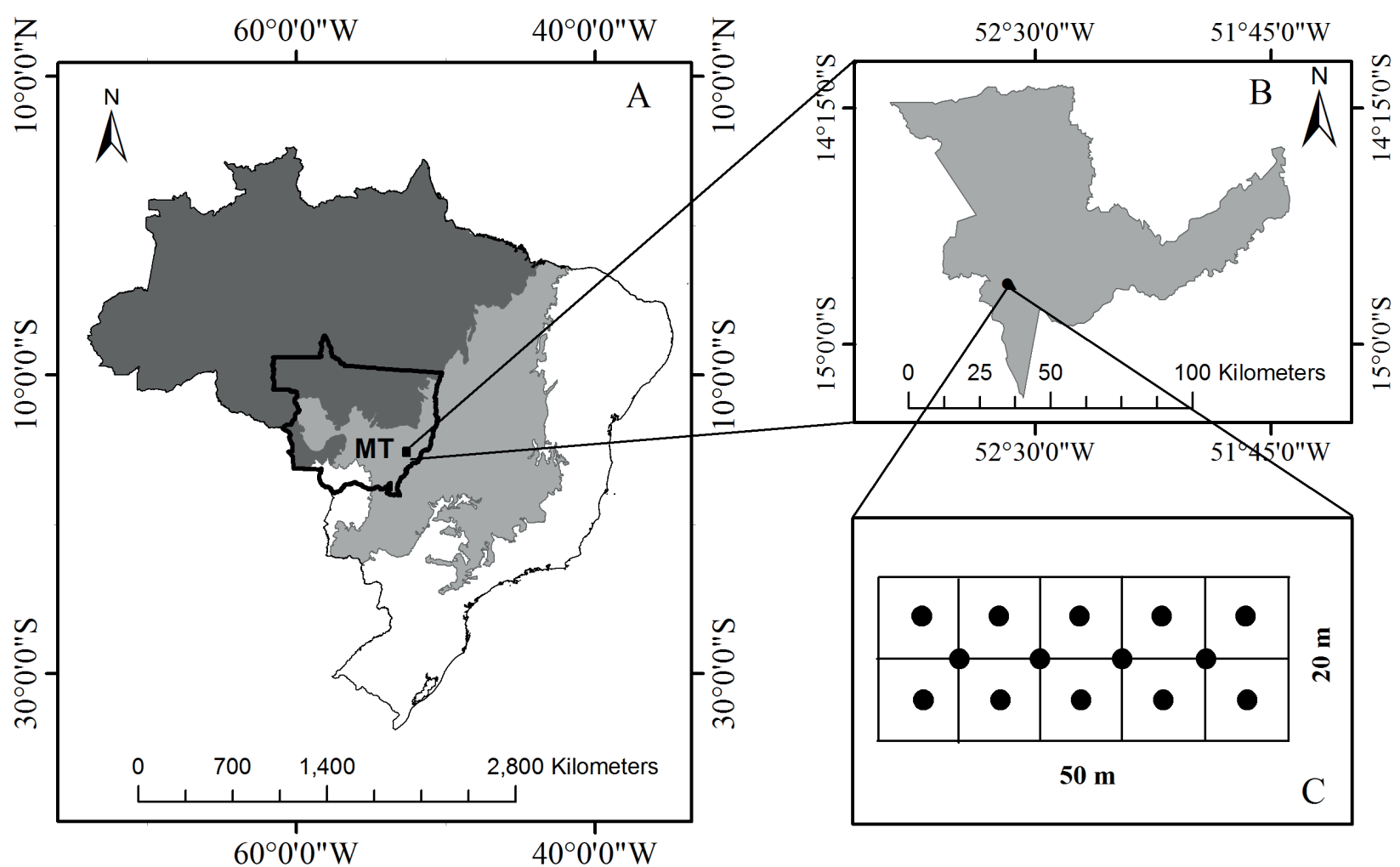

Figure 1. A-C. Location of study area in eastern Mato Grosso, Brazil, and the study plots before and after the occurrence of fire. $\mathrm{A}=$ Brazil, showing the state of Mato Grosso (MT) and the Amazon (dark gray) and Cerrado (light gray) biomes, according to the classification of Brazilian Institute of Geography and Statistics (IBGE); B = Municipality of Nova Xavantina, showing the study area. $C=$ Schematic diagram of the ten subplots used to sample the shrub-tree vegetation at each savanna site, showing the points used for the collection of the samples of grass and rock cover in deep soil and rocky savannas, as well as the rockiness of the latter habitat.

the first inventory but dead (aboveground biomass) during the second survey were recorded as dead, even though the underground organs of Cerrado plants may often remain alive (Hoffmann \& Solbrig 2003). Therefore, the presence of basal shoots in these plants was also verified. During the second inventory, we estimated the grassy cover in the DS and RS savannas to obtain an indirect measure of the severity of the fire, given that, in the Cerrado, the undergrowth stratum, which includes grasses, comprises the main source of combustible material during the dry season (Miranda et al. 1993). This substrate was estimated in a $0.5 \mathrm{~m} \times 0.5 \mathrm{~m}$ grid subdivided into 25 quadrants of $0.1 \mathrm{~m} \times 0.1 \mathrm{~m}$. These samples were obtained at 14 points, with a distance of $5 \mathrm{~m}$ between adjacent points, distributed regularly within the plot (Fig. 1C). At each point, the grid was set up at a height of $0.5 \mathrm{~m}$ above the ground, and the grass or rocks found in each grid square were quantified. The cover was scored as 0 for the total absence of rocks or grasses, 0.5 for a cover of up to $50 \%$, and 1 for a cover of more than $51 \%$. To avoid bias in these estimates, we calculated the arithmetic mean of the values obtained by two different researchers to obtain a measure of the cover at each point. In this case, the minimum and maximum values were 0 (no cover) and 25 (all 25 quadrants with a cover of at least $50 \%$ ), respectively. We then calculated the arithmetic mean of the 14 estimates to provide a general estimate of the grass cover in the 10 plots, as well as the percentage of rocky cover in the RS.

\section{Data analysis}

We used Sørensen (qualitative) and Morisita (quantitative) indices (Brower \& Zar 1984) to compare the similarity of the species composition between sites, and at the same site between years (before and after the fire). We applied a Principal Coordinates Analysis (PCoA) to the data on species composition and density, to order the plots, including both pre- and post-fire sampling. We then used an ANOSIM (Clarke \& Warwick 1994) to test the significance of the groups formed in the PCoA - DS savanna before (DSBF) and after the fire (DSAF) and RS savannas before (RSBF) and after the fire (RSAF).

We produced rarefaction curves based on the adjustment 
of the number of plants to compare the estimates of species richness (Gotelli \& Colwell 2001) within and between as communities before and after the fire. We used diversity profiles based on the Rényi exponential series (Tóthmérész 1995) to compare the diversity of species between sites and inventories. This method permits the integrated application of a whole family of diversity indices, ranging from those which give more weight to the rare species to those that prioritize the influence of abundant species.

We used a paired $t$ test to compare the mean densities of plants and the basal area of the live plants found in each plot in each community between years. We also compared the mean grassy cover by using the Mann-Whitney test. We then compared the frequency of dead plants sprouting and not sprouting in the two communities using Chi-square with Yates' correction. We adopted a $5 \%$ significance level for all analyses.

\section{Results}

We recorded 99 species in the two communities, both before and after the fire (Tab. 1). Before the fire, the two communities had 45 species ( $46 \%$ of the total) in common, and after the fire, 44 (45\%). There was thus no evidence of any change in the similarity of the composition of the DS and RS savannas following the fire (Tab. 2). A certain amount of variation was also found in the similarity indices when considering the same community before and after the fire (Tab. 2). In this case, the fire neither increased nor decreased the similarity of the two communities, and did not induce any major alteration in the species composition of either phytophysiognomy (Fig. 2). These results were also confirmed by the PCoA (Fig. 2), given that the two groups (DS and RS savannas) established before the fire presented minor alterations after the fire (axis $1=53.69 \%$; axis $2=10.09 \%)$ and were confirmed by the ANOSIM $(R=$ $0.593 ; p<0.001)$.

Minor changes were also found in the densities of the plant species after the fire in the two communities. None of the most abundant species (represented by at least 20 plants) suffered a loss of more than $10 \%$ of their abundance in the RS savanna following the fire, and only Myrcia lanuginosa (reduction of 16.5\%), Heteropterys byrsnonimifolia (13.6\%) and Hymenaea stignocarpa (12.5\%) were severely affected in the DS savanna. No increase in abundance exceeding $5 \%$ was recorded in any of the more abundant species. In the case of the least abundant species ( $\mathrm{n}=1$ plant per site),

Table 1. Species abundance of the woody vegetation of the adjacent deep soil (DS) and rocky soil (RS) savannas before (BF) and after (AF) the fire that occurred in September 2014, in the municipality of Nova Xavantina, Mato Grosso, Brazil. The species are sorted by the sum of columns (DSBF, DSAF, RSBF, RSAF).

\begin{tabular}{|c|c|c|c|c|c|}
\hline Species & Families & DSAF & DSBF & RSAF & RSBF \\
\hline Qualea parviflora Mart. & Vochysiaceae & 205 & 196 & 160 & 160 \\
\hline Syagrus flexuosa (Mart.) Becc. & Arecaceae & - & - & 151 & 150 \\
\hline Davilla elliptica A.St.-Hil. & Dilleniaceae & 56 & 53 & 84 & 88 \\
\hline Pouteria ramiflora (Mart.) Radlk. & Sapotaceae & 109 & 105 & 30 & 28 \\
\hline Myrcia lanuginosa O.Berg & Myrtaceae & 121 & 101 & 5 & 5 \\
\hline Eugenia aurata O.Berg & Myrtaceae & 23 & 23 & 71 & 69 \\
\hline Heteropterys byrsonimifolia A.Juss. & Malpighiaceae & 22 & 19 & 64 & 64 \\
\hline Kielmeyera rubriflora Cambess. & Calophyllaceae & 35 & 35 & 48 & 48 \\
\hline Vatairea macrocarpa (Benth.) Ducke & Fabaceae & 9 & 9 & 65 & 68 \\
\hline Qualea multiflora Mart. & Vochysiaceae & 8 & 9 & 64 & 63 \\
\hline Hymenaea stigonocarpa Mart. ex Hayne & Fabaceae & 40 & 35 & 32 & 32 \\
\hline Syagrus comosa (Mart.) Mart. & Arecaceae & 57 & 57 & 11 & 11 \\
\hline Ouratea hexasperma (A.St.-Hil.) Baill. & Ochnaceae & 54 & 52 & - & - \\
\hline Qualea grandiflora Mart. & Vochysiaceae & 36 & 35 & 17 & 17 \\
\hline Ouratea spectabilis (Mart.) Engl. & Ochnaceae & 27 & 26 & 27 & 25 \\
\hline Plathymenia reticulata Benth. & Fabaceae & 1 & 1 & 52 & 48 \\
\hline Mouriri pusa Gardner & Melastomataceae & 25 & 25 & 24 & 24 \\
\hline Andira cujabensis Benth. & Fabaceae & 41 & 40 & 7 & 7 \\
\hline Pterodon pubescens (Benth.) Benth. & Fabaceae & 8 & 8 & 39 & 38 \\
\hline Lafoensia pacari A.St.-Hil. & Lythraceae & 6 & 6 & 37 & 37 \\
\hline Vochysia rufa Mart. & Vochysiaceae & 44 & 40 & - & - \\
\hline Couepia grandiflora (Mart. \& Zucc.) Benth. & Chrysobalanaceae & 39 & 39 & - & - \\
\hline Salvertia convallariodora A.St.-Hil. & Vochysiaceae & 33 & 33 & 6 & 6 \\
\hline Erythroxylun suberosum A.St.-Hil. & Erythroxylaceae & 11 & 9 & 27 & 27 \\
\hline Mezilaurus crassiramea (Meisn.) Taub. ex Mez & Lauraceae & 34 & 33 & 2 & 2 \\
\hline
\end{tabular}


Eddie Lenza, Ana Clara Abadia, Hélio Menegat, Nadjarriny W. Lúcio, Leonardo Maracahipes-Santos,
Henrique A. Mews, Josias O. dos Santos and Jhany Martins

Table 1. Cont.

\begin{tabular}{|c|c|c|c|c|c|}
\hline Species & Families & DSAF & DSBF & RSAF & RSBF \\
\hline Aspidosperma tomentosum Mart. & Apocynaceae & 32 & 31 & 1 & 1 \\
\hline Magonia pubescens A.St.-Hil. & Sapindaceae & - & - & 33 & 30 \\
\hline Tabebuia aurea (Silva Manso) Benth. \& Hook.f. ex S.Moore & Bignoniaceae & 19 & 18 & 10 & 10 \\
\hline Licania humilis Cham. \& Schltdl. & Chrysobalanaceae & 28 & 27 & - & - \\
\hline Byrsonima coccolobifolia Kunth & Malpighiaceae & 21 & 20 & 7 & 7 \\
\hline Kielmeyera coriacea Mart. \& Zucc. & Calophyllaceae & 17 & 16 & 10 & 10 \\
\hline Byrsonima pachyphylla A.Juss. & Malpighiaceae & 13 & 11 & 14 & 13 \\
\hline Eugenia gemmiflora O.Berg & Myrtaceae & 12 & 12 & 13 & 12 \\
\hline Pseudobombax longiflorum (Mart. \& Zucc.) A.Robyns & Malvaceae & - & - & 24 & 24 \\
\hline Erythroxylum tortuosum Mart. & Erythroxylaceae & 16 & 15 & 6 & 8 \\
\hline Cordiera sessilis (Vell.) Kuntze & Rubiaceae & - & - & 22 & 22 \\
\hline Tachigali aurea Tul. & Fabaceae & 13 & 12 & 9 & 9 \\
\hline Eugenia sp.1 & Myrtaceae & - & - & 21 & 21 \\
\hline Aspidosperma multiflorum A.DC. & Apocynaceae & - & - & 18 & 18 \\
\hline Leptolobium dasycarpum Vogel & Fabaceae & 2 & 2 & 15 & 15 \\
\hline Guapira graciliflora (Mart. ex Schmidt) Lundell & Nyctaginaceae & 1 & 1 & 15 & 15 \\
\hline Diospyros hispida A.DC. & Ebenaceae & 16 & 14 & - & - \\
\hline Eriotheca gracilipes (K.Schum.) A.Robyns & Malvaceae & 1 & 1 & 14 & 14 \\
\hline Salacia crassifolia (Mart. ex Schult.) G.Don & Celastraceae & 14 & 14 & - & - \\
\hline Astronium fraxinifolium Schott & Anacardiaceae & - & - & 14 & 14 \\
\hline Callisthene fasciculata Mart. & Vochysiaceae & - & - & 14 & 14 \\
\hline Curatella americana $\mathrm{L}$. & Dilleniaceae & - & - & 14 & 14 \\
\hline Heisteria ovata Benth. & Olacaceae & - & - & 14 & 14 \\
\hline Mouriri elliptica Mart. & Melastomataceae & 10 & 10 & 3 & 3 \\
\hline Dimorphandra mollis Benth. & Fabaceae & 2 & 2 & 11 & 9 \\
\hline Eschweilera nana (O.Berg) Miers & Lecythidaceae & 12 & 10 & - & - \\
\hline Bowdichia virgilioides Kunth & Fabaceae & 6 & 6 & 5 & 5 \\
\hline Peltogyne confertiflora (Mart. ex Hayne) Benth. & Fabaceae & 3 & 3 & 6 & 6 \\
\hline Buchenavia tomentosa Eichler & Combretaceae & 9 & 7 & - & - \\
\hline Handroanthus ochraceus (Cham.) Mattos & Bignoniaceae & 6 & 6 & 2 & 2 \\
\hline Tocoyena formosa (Cham. \& Schltdl.) K.Schum. & Rubiaceae & 5 & 5 & 3 & 3 \\
\hline Jacaranda brasiliana (Lam.) Pers. & Bignoniaceae & - & - & 8 & 8 \\
\hline Fridericia cinnamomea (DC.) L.G.Lohmann & Bignoniaceae & - & - & 7 & 8 \\
\hline Byrsonima verbascifolia (L.) DC. & Malpighiaceae & 6 & 6 & - & - \\
\hline Eugenia punicifolia (Kunth) DC. & Myrtaceae & 6 & 6 & - & - \\
\hline Machaerium acutifolium Vogel & Fabaceae & 5 & 3 & 2 & 2 \\
\hline Emmotum nitens (Benth.) Miers & Icacinaceae & 4 & 5 & 1 & 1 \\
\hline Guapira noxia (Netto) Lundell & Nyctaginaceae & 5 & 5 & - & - \\
\hline Annona coriacea Mart. & Annonaceae & 2 & 2 & 2 & 2 \\
\hline Copaifera langsdorffii Desf. & Fabaceae & - & - & 4 & 4 \\
\hline Kielmeyera sp. & Calophyllaceae & - & - & 4 & 4 \\
\hline Myrcia camapuanensis N.Silveira & Myrtaceae & - & - & 4 & 4 \\
\hline Norantea guianensis Aubl. & Marcgraviaceae & - & - & 4 & 4 \\
\hline Psidium laruotteanum Cambess. & Myrtaceae & 1 & 1 & 2 & 2 \\
\hline Roupala montana Aubl. & Proteaceae & 1 & 1 & 2 & 2 \\
\hline Aspidosperma macrocarpon Mart. & Apocynaceae & - & - & 3 & 3 \\
\hline Aspidosperma nobile Müll.Arg. & Apocynaceae & - & - & 3 & 3 \\
\hline Himatanthus obovatus (Müll. Arg.) Woodson & Apocynaceae & - & - & 3 & 3 \\
\hline Protium heptaphyllum (Aubl.) Marchand & Burseraceae & - & - & 3 & 3 \\
\hline Connarus suberosus Planch. & Connaraceae & 2 & 2 & - & - \\
\hline Eugenia sp.2 & Myrtaceae & 2 & 2 & - & - \\
\hline Strychnos pseudoquina A.St.-Hil. & Loganiaceae & 2 & 2 & - & - \\
\hline Stryphnodendron rotundifolium Mart. & Fabaceae & 2 & 2 & - & - \\
\hline Tachigali subvelutina (Benth.) Oliveira-Filho & Fabaceae & 2 & 2 & - & - \\
\hline Neea theifera Oerst. & Nyctaginaceae & 1 & 1 & 1 & 1 \\
\hline
\end{tabular}


Table 1. Cont.

\begin{tabular}{|c|c|c|c|c|c|}
\hline Species & Families & DSAF & DSBF & RSAF & RSBF \\
\hline Cybistax antisyphilitica (Mart.) Mart. & Bignoniaceae & - & - & 2 & 2 \\
\hline Diplopterys pubipetala (A.Juss.) W.R.Anderson \& C.C.Davis & Malpighiaceae & - & - & 2 & 2 \\
\hline Dipteryx alata Vogel & Fabaceae & - & - & 2 & 2 \\
\hline Simarouba versicolor A.St.-Hil. & Simaroubaceae & - & - & 2 & 2 \\
\hline Erythroxylum engleri O.E.Schulz & Erythroxylaceae & 1 & 1 & 1 & - \\
\hline Agonandra brasiliensis Miers ex Benth. \& Hook.f. & Opiliaceae & 1 & 1 & - & - \\
\hline Annona crassiflora Mart. & Annonaceae & 1 & 1 & - & - \\
\hline Dalbergia miscolobium Benth. & Fabaceae & 1 & 1 & - & - \\
\hline Hancornia speciosa Gomes & Apocynaceae & 1 & 1 & - & - \\
\hline Handroanthus serratifolius (Vahl) S.Grose & Bignoniaceae & 1 & 1 & - & - \\
\hline Rourea induta Planch. & Connaraceae & 1 & 1 & - & - \\
\hline Alibertia edulis (Rich.) A.Rich. & Rubiaceae & - & - & 1 & 1 \\
\hline Enterolobium gummiferum (Mart.) J.F.Macbr. & Fabaceae & - & - & 1 & 1 \\
\hline Erythroxylum daphnites Mart. & Myrtaceae & - & - & 1 & 1 \\
\hline Hirtella gracilipes (Hook.f.) Prance & Chrysobalanaceae & - & - & 1 & 1 \\
\hline Luetzelburgia praecox (Harms) Harms & Fabaceae & - & - & 1 & 1 \\
\hline Myrcia tomentosa (Aubl.) DC. & Myrtaceae & - & - & 1 & 1 \\
\hline Miconia albicans (Sw.) Triana & Melastomataceae & 1 & - & - & - \\
\hline Myrcia multiflora (Lam.) DC. & Myrtaceae & - & - & - & 1 \\
\hline Total geral & & 1351 & 1279 & 1409 & 1399 \\
\hline
\end{tabular}

Table 2. Similarity of the species composition (Sørensen in the upper diagonal and Morisita in the lower diagonal) of the adjacent DS and RS savannas before $(\mathrm{BF})$ and $(\mathrm{AF})$ after the fire, in the municipality of Nova Xavantina, Mato Grosso, Brazil.

\begin{tabular}{|c|c|c|c|c|}
\hline & DSBF & DSAF & RSBF & RSAF \\
\hline DSBF & 1 & 0.993 & 0.62 & 0.633 \\
\hline DSAF & 0.998 & 1 & 0.615 & 0.629 \\
\hline RSBF & 0.582 & 0.573 & 1 & 0.986 \\
\hline RSAF & 0.581 & 0.572 & 0.999 & 1 \\
\hline
\end{tabular}

Erythroxylum engleri was recorded in the RS savanna only before the fire, and Myrcia multiflora only after the fire. In the DS savanna, one plant of Miconia albicans was recorded only after the fire. No other species represented by at least two individuals arose or disappeared between inventories.

In the RS savanna, we recorded 76 species before fire and 75 after the fire, while in the DS savanna, there were 68 species before the fire, and 67 afterwards. The species richness of the RS savanna was consistently higher than that of the DS savanna, although there was no major change in either community following the fire (Fig. 3). Similarly, the RS savanna had higher species diversity than the DS savanna both before and after the fire (Fig. 4). However, no major change in diversity was found after the fire in either community (Fig. 4).

The post-fire mortality rate in the DS savanna was double that of the RS savannas, and the recruitment rate was two times lower in the DS savanna (Tab. 3). Given this, there was a significant reduction (5.3\%) in the density of live plants in the DS savanna following the fire $(t=2.893$; $p=$

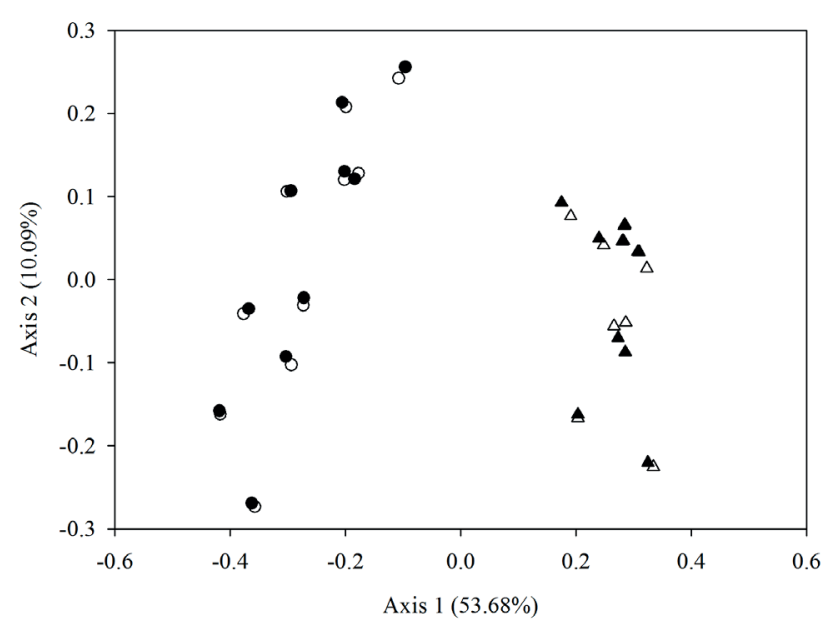

Figure 2. Ordination plot of the $\mathrm{PCoA}$ for the species composition of the deep soil savanna before (DSBF, $\triangle$ ) and after the fire (DSAF, $\boldsymbol{\Delta})$, and the rocky soil savanna before (RSBF, ○) and after (RSAF, $\bullet$ ) the fire, in the municipality of Nova Xavantina, Mato Grosso, Brazil.

$0.018)$, but a much more discreet reduction $(0.7 \%)$ in the RS savanna ( $t=0.595 ; p=0.566$ ). Similarly, while there was a significant loss of basal area in the DS savanna ( $t=2.72$; $p=$ $0.023)$, no such tendency was found in the RS savanna ( $t=$ $0.351 ; p=0.733)$. The frequency of dead plants with basal sprouting after the fire was significantly higher in the DS savanna in comparison with the RS savanna $\left(\chi^{2}=6.830, p=\right.$ 0.009). Eight months after the fire, the grass cover of the DS savanna was significantly greater than that recorded in the RS savanna ( $U=5.26 ; p<0.0001$ (Tab. 3). 


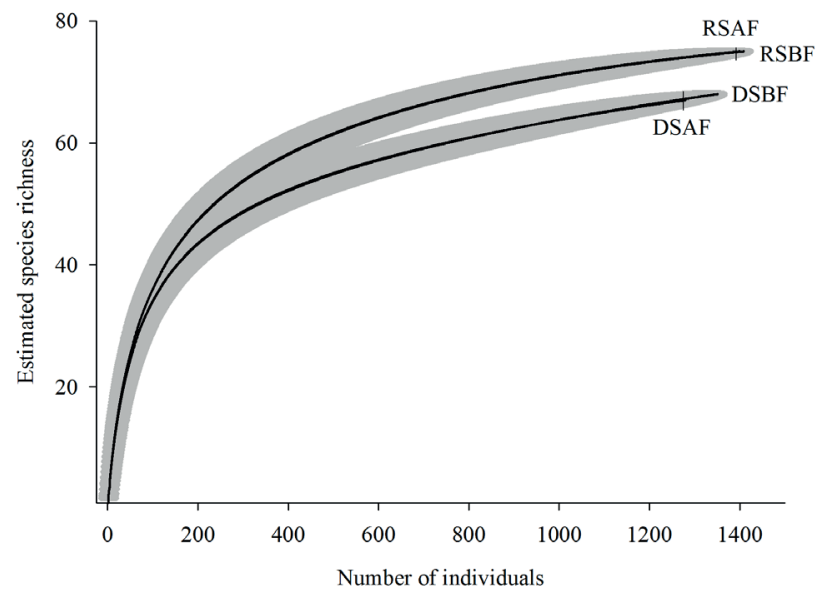

Figure 3. Estimated species richness the deep soil savanna before (DSBF) and after the fire (DSAF), and the rocky soil savanna before (RSBF) and after (RSAF) the fire, in the municipality of Nova Xavantina, Mato Grosso, Brazil. The 95 \% confidence interval is shaded in gray and the vertical line at the end of each curve represents the point of comparison pre- and post-fire.

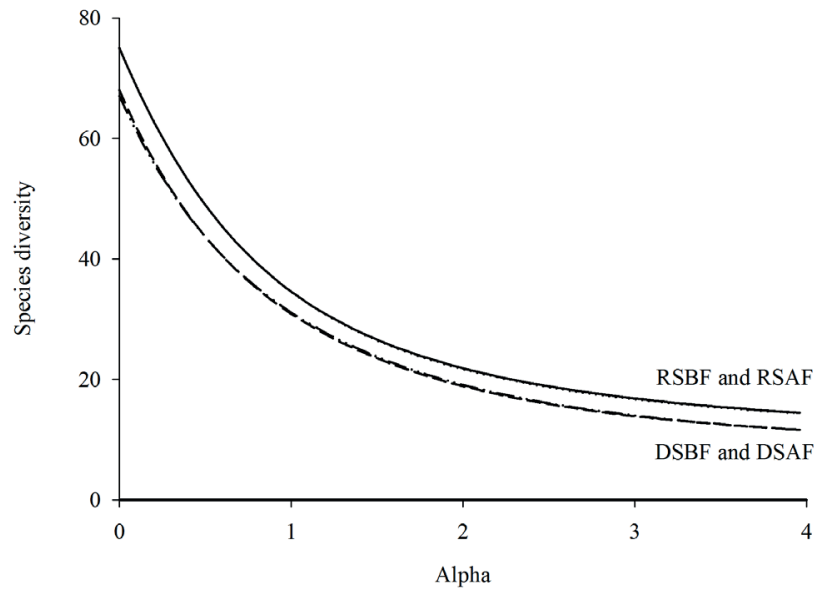

Figure 4. Profiles of species diversity of the deep soil savanna (dotted line) before (DSBF) and after the fire (DSAF), and the rocky soil savanna (solid line) before (RSBF) and after (RSAF) the fire, in the municipality of Nova Xavantina, Mato Grosso, Brazil.

Table 3. Structural parameters of the woody vegetation of the adjacent deep soil (DS) and rocky soil (RS) savanna, before and after the fire, in the municipality of Nova Xavantina, Mato Grosso, Brazil. For plant density (in 10 plots of $20 \mathrm{~m} \times 50 \mathrm{~m}$ ), basal area, and grassy cover, the values are means followed by their standard deviations. Values associated with different letters are significantly different $(p<0.05)$ in the paired t test for density of plants and basal area, and Mann-Whitney test for grass cover.

\begin{tabular}{|c|c|c|c|c|}
\hline & \multicolumn{2}{|c|}{ DS savanna } & \multicolumn{2}{c|}{ RS savanna } \\
\hline Parameter & Before the fire & After the fire & Before the fire & After the fire \\
\hline Density of plants & $135.1 \pm 24.25^{\mathrm{a}}$ & $127.9 \pm 21.70^{\mathrm{b}}$ & $140.9 \pm 33.39^{\mathrm{a}}$ & $139.9 \pm 33.17^{\mathrm{a}}$ \\
\hline Basal area (m ( $^{2}$ a) & $1.53 \pm 0.25^{\mathrm{a}}$ & $1.48 \pm 0.24^{\mathrm{b}}$ & $1.23 \pm 0.29^{\mathrm{a}}$ & $1.23 \pm 0.29^{\mathrm{a}}$ \\
\hline Recruitment (\%) & & 0.66 & 1.9 \\
\hline Mortality (\%) & & 5.6 & 2.6 \\
\hline Dead with sprouting (n) & & 59 & 18 \\
\hline Dead with no sprouting (n) & & $11.5 \pm 6.44^{\mathrm{a}}$ & 18 \\
\hline Grass cover (n) & 0 & $3.38 \pm 7.99^{\mathrm{b}}$ \\
\hline Rocky Cover (\%) & & & 67.5 \\
\hline
\end{tabular}

*Estimated value (see Material and Methods for details).

\section{Discussion}

Differences in the species composition of woody savanna communities on different types of substrate have also been recorded in other studies on local (Gomes et al. 2011; Abreu et al. 2012) and regional scales (Mews et al. 2014). However, we found no evidence of any homogenization or simplification of the species composition of the two communities, nor any shift in the species diversity of either community, following the fire. However, these findings should be considered with caution, as the high frequency of fires in the years prior to the period of the present study (five events - virtually one every two years - between 2004 and 2014 at the two sites) may have resulted in the loss of the most sensitive species that are locally rare. A similar situation has been observed in other fire-affected areas of the cerrado (Sato \& Miranda 1996; Silva et al. 1996; Gomes et al. 2014), as well as the present study, in which the two species excluded after the fire, Miconia albicans in the DS and Erythroxylum engleri in the RS, were each represented by only a single specimen prior to the fire.

Following fires, minor changes been observed in the species richness and composition of savannas on shallow, rocky, and hilly substrates (Gomes et al. 2014) and also on deep soils and flat terrain (Silva et al. 1996; Lima et al. 2009; Lopes et al. 2009; Ribeiro et al. 2012) in Brazil, as well as in savanna communities in other parts of the world (Higgins et al. 2000; 2007). However, fires may also cause considerable impacts on species richness and composition, 
as recorded by Mews et al. (2013). These inconsistencies are probably the result of the distinct history of wildfires in each community. The Cerrado studied by Mews et al. (2013) was protected from fire for more than a decade, while the two savannas studied here had been burned off every other year over the past 10 years. This may have determined the accumulation of fine-stemmed and inflammable biomass in the savanna studied by Mews et al. (2013), resulting in more intense fires (Pivello \& Norton 1996; Pivello 2006; França et al. 2007; Higgins et al. 2007), which had a greater impact on the flora. In areas with a prolonged absence of fire, the establishment of more fire-sensitive plant species will tend to be more likely (Moreira 2000), making these habitats more vulnerable to fire-induced changes in composition.

The low mortality rates recorded here in both the DS $(5.6 \%)$ and the RS savannas (2.6\%) were much lower than those recorded in other studies of woody Cerrado savanna communities following fires, whether on deep soils, i.e. $41 \%$ in Hoffmann et al. (2009), 67.4 \% in Mews et al. (2013), and $13-16 \%$ in Sato \& Miranda (1996), or shallow ones, i.e., $43.6 \%$ in Gomes et al. (2014). These mortality rates caused a significant reduction in the abundance of trees and shrubs in the Cerrado, in contrast with the pattern observed in the present study (Sato \& Miranda 1996; Fiedler et al. 2004; Lima et al. 2009; Mews et al. 2013). We believe that the low mortality rates recorded in the present study are related to the relatively high frequency of fires in the two studied savannas. In the Cerrado, fires are known to cause higher mortality rates in plants of smaller size (Hoffmann \& Solbrig 2003; Gomes et al. 2014) and will decimate or eliminate the populations of the more sensitive species. In this case, recurring fires prior to the one observed in the present study may have filtered out most of the smaller individuals and the species most sensitive to the effects of fire. In this scenario, the remaining individuals in 2014 were likely to have been the least susceptible to fire.

More intense fires increase mortality rates in the Cerrado (Hoffmann \& Solbrig 2003). In the present study, the more significant reduction in plant density observed in the DS savanna indicates that the effects of the fire were more severe in this environment than in the RS savanna. This appears to have been related to the larger quantity of biomass found in the grassy-herbaceous stratum of the DS savanna, given that these plants represent the main source of fine-grade combustible material that fuels wildfires (Miranda et al. 2002). In this case, the presence of rocky outcrops in the RS savanna limits the establishment of grasses, and thus restricts the accumulation of biomass, resulting in less severe fires in this community in comparison with the DS savanna. This conclusion is reinforced by the fact that the fire did not affect seven RS subplots in any way, due to the rocky substrate and the absence of combustible material, while in the DS savanna, all the subplots were burnt completely.

Fire is known to cause a major loss in the basal area of live plants in the savanna communities of the Cerrado sensu stricto growing on deep soils (Mews et al. 2011) and on shallow soils interspersed with rocky outcrops (Gomes et al. 2014). However, the present study is the first to compare the effects of fire on the mortality and live biomass of adjacent areas of DS and RS savanna. In the present study at two sites with a high frequency of fires over the preceding 10 years, we found lower mortality rates and a reduced loss of basal area at both sites, regardless the substrate, in comparison with other studies (Mews et al. 2011; Gomes et al. 2014). Based on this, we conclude that the effects of fire on the resistance of the woody community, also depends on the history (frequency) of fire at each site, a phenomenon that demands more attention in future studies.

The higher stem mortality rate (topkill) and the greater loss of aboveground basal area recorded in the DS savanna in comparison with the RS appear to have been compensated by a higher frequency of basal sprouting. This mechanism has been recorded amply in the woody savanna communities of the Cerrado and other savannas worldwide (Higgins et al. 2000; Hoffmann \& Solbrig 2003). However, despite the much lower topkill recorded in the RS savanna, the capacity for basal sprouting in this vegetation was also reduced. We believe that the partial or total lack of soil in the RS savanna constitutes a limiting factor for the basal sprouting capacity of this community, particularly because, in these environments, the hydrological deficit tends to be extremely high during the dry season (Oliveira-Filho \& Martins 1986). In this case, while the rocky outcrops of the RS savanna may contribute to a reduction of the severity of the effects of fires - and consequently, plant mortality - they may also restrict the basal sprouting capacity of the plants burned by the flames. Interestingly, after the fire, the recruitment of individuals was three times greater in the RS than in DS. On this, we believe that in the RS savanna the fire may have caused less mortality in individuals with potential for recruitment, i.e., those with a stem diameter lower than the minimum threshold $(5 \mathrm{~cm})$ adopted in the present study, as there are fewer grasses and, therefore, less availability of fine fuels, which can make fires less severe and harmful.

We conclude that fire did not have differential effects on the species composition and diversity of the woody savannas growing on different substrates, although it has an impact on both. Even so, the post-fire dynamics of the two studied areas indicate that vegetation structural changes are more pronounced in savannas with a large and more continuous grassy-herbaceous stratum. Thus, our findings suggest that savannas more threatened by the expansion of agriculture in Brazil (i.e., DS savannas; Mews et al. 2014) may have their vegetation more structurally impacted by fire, which constitutes another erosion factor of biodiversity in savannas of Cerrado in the Central Brazil. In addition, we also showed, for the first time, a probable trade-off between mortality and basal sprouting in the two communities, characterized by greater resistance and reduced resilience, in short time, in the community of woody plants of the 
rocky soil savanna, in contrast with low resistance and high resilience of the deep soil savanna. However, our conclusions are limited to the understanding of the immediate response of the vegetation (less than one year) and the findings do not provide direct insights into the behavior of fire in the two physiognomies. In this case, longer periods of monitoring (e.g., Gomes et al. 2014 in the RS) in a larger area of habitat will be necessary to better comprehend the pattern of fire impact and the resistance and resilience of the DS and RS to fire, and the consequences of fire for the conservation of the flora of these two physiognomies.

\section{Acknowledgements}

We would like to thank the taxonomists Carolyn Elinore Barnes Proença and Jair Eustáquio Quintino de Faria Júnior for the identification of the species of the family Myrtaceae. We are grateful to the Brazilian Coordination for Higher Education Training (CAPES) for financial support through the PROCAD UnB/UNEMAT project (process 88881.0684302014-01). We also thank the Brazilian National Council for Technological and Scientific Development (CNPq) for financial support through the SISBIOTA (process 5633202010-9), PPBio Cerrado (process 457587-2012) and the project 447542/2014-1.

\section{References}

Abreu MF, Pinto JRR, Maracahipes L, et al. 2012. Influence of edaphic variables on the floristic composition and structure of the tree-shrub vegetation in typical and rocky outcrop cerrado areas in Serra Negra, Goiás State, Brazil. Brazilian Journal of Botany 35: 259-272.

APG - Angiosperm Phylogeny Group IV. 2016. An update of the Angiosperm Phylogeny Group classification for the orders and families of flowering plants: APG IV. Botanical Journal of the Linnean Society 181: 1-20.

Bond WJ, Keeley JE. 2005. Fire as a global 'herbivore': the ecology and evolution of flammable ecosystems. Trends in Ecology and Evolution 20: 387-394.

Brower J, Zar J. 1984. Field and laboratory methods for general ecology. Boston, W.C. Brown Publishers.

Carvalho GH, Batalha MA, Cianciaruso M, Silva IA, Petchey OL. 2014. Are fire, soil fertility and toxicity, water availability, plant functional diversity, and litter decomposition related in a Neotropical savanna?. Oecologia 175: 923-935.

Clarke KR, Warwick RM. 1994. Change in Marine Communities: An Approach to statistical analysis and interpretation. Bournemouth, Natural Environment Research Council.

Collinson AS. 1988. Tropical formations with conspicuous grasslands: savannas. In: Collinson AS. (ed.) Introduction to World Vegetation. London, Unwin Hyman Ltd. p. 232-248.

Dantas VDL, Pausas JG. 2013. The lanky and the corky: fireescape strategies in savanna woody species. Journal of Ecology 101: 1265-1272.

Dantas VL, Batalha MA, Pausas JG. 2013. Fire drives functional thresholds on the savanna - forest transition. Ecology 94: 2454-2463.

D’Odorico P, Laio F, Ridolfi L. 2006. A Probabilistic Analysis of Fire-Induced Tree-Grass Coexistence in Savannas. The American Naturalist 167: 80-87.

Felfili JM, Carvalho F, Haidar R. 2005. Manual para o monitoramento de parcelas permanentes nos biomas Cerrado e Pantanal. Brasília, Universidade de Brasília.
Felfili JM, Rezende AV, Silva Junior MC, Silva MA. 2000. Changes in the floristic composition of cerrado sensu stricto in Brazil over a nine-year period. Journal of Tropical Ecology 16: 579-590.

Fiedler NC, Azevedo INC, Rezende AV, Medeiros M. B, Ventuoili F. 2004. Efeito de incêndios florestais na estrutura e composição florística de uma área de cerrado sensu stricto na Fazenda Água Limpa, DF. Revista Árvore 28: 129-138.

França H, Ramos-Neto M, Setzer A. 2007. O fogo no Parque Nacional das Emas. Vol. 27 Série Biodiversidade. Brasília, Ministério do Meio Ambiente.

Geiger EL, Gotsch SG, Damasco G, Haridasan M, Franco AC, Hoffmann WA. 2011. Distinct roles of savanna and forest tree species in regeneration under fire suppression in a Brazilian savanna. Journal of Vegetation Science 22: 312-321.

Gomes L, Lenza E, Maracahipes L, Marimon BS, Oliveira EA. 2011. Comparações florísticas e estruturais entre duas comunidades lenhosas de cerrado típico e cerrado rupestre, Mato Grosso, Brasil. Acta Botanica Brasilica 25: 865-875.

Gomes L, Maracahipes L, Marimon BS, et al. 2014. Post-fire recovery of savanna vegetation from rocky outcrops. Flora 209: 201-208.

Gotelli NJ, Colwell RK. 2001. Quantifying biodiversity: procedures and pitfalls in the measurment and comparison of species richness. Ecology Letters 4: 379-391.

Higgins SI, Bond WJ, February EC, et al. 2007. Effects of four decades of fire manipulation on woody vegetation structure in savanna. Ecology 88: 1119-1125.

Higgins SI, Bond WJ, Trollope WSW. 2000. Fire, resprouting and variability: a recipe for grass- tree coexistence in savanna. Journal of Ecology 88: 213-229.

Hoffmann WA. 1996. The effects of fire and cover on seedling establishment in a Neotropical savanna. Journal Ecology 84: 383-393.

Hoffmann WA. 1998. Post-burn reproduction of woody plants in a neotropical savanna: the relative importance of sexual and vegetative reproduction. Journal of Applied Ecology 35: 422-433.

Hoffmann WA, Adasme R, Haridasan M, et al. 2009. Tree topkill, not mortality, governs the dynamics of savanna-forest boundaries under frequent fire in central Brazil. Ecology 90: 1326-1337.

Hoffmann WA, Moreira AG. 2002. The role of fire in population dynamics of woody plants. In: Oliveira OS, Marquis RJ. (eds.) Cerrados of Brazil. New York, Columbia University Press. p. 159-177.

Hoffmann WA, Solbrig OT. 2003. The role of topkill in the differential response of savanna woody species to fire. Forest Ecology and Management 180: 273-286.

Klink CA, Machado RB. 2005. A conservação do Cerrado brasileiro. Megadiversidade 1: 147-155.

Lehmann CER, Anderson TM, Sankaran M, et al. 2014. Savanna vegetationfire-climate relationships differ among continents. Science 343: 548542.

Libano AM, Felfili JM. 2006. Mudanças temporais na composição florística e na diversidade de um cerrado sensu stricto do Brasil Central em um período de 18 anos (1985-2003). Acta Botanica Brasilica 20: 927-936.

Lima EDS, Lima HS, Ratter JA. 2009. Mudanças pós-fogo na estrutura e composição da vegetação em um Cerrado Mesotrófico, no período de cinco anos (1997-2002) em Nova Xavantina - MT. Cerne 15: 468-480.

Lista de Espécies da Flora do Brasil. 2015. Jardim Botânico do Rio de Janeiro. <http://floradobrasil.jbrj.gov.br/>. 9 Feb. 2016.

Lopes SF, Vale VS, Schiavini I. 2009. Efeito de queimadas sobre a estrutura e composição da comunidade vegetal lenhosa do Cerrado Sentido Restrito em Caldas Novas, GO. Revista Árvore 33: 695-704.

Marimon BS, Felfili JM 2006. Chuva de sementes em uma floresta monodominante de Brosimum rubescens Taub. e em uma floresta mista adjacente no Vale do Araguaia, MT, Brasil. Acta Botanica Brasilica 20: 423-432.

Medeiros MB, Miranda HS. 2005. Mortalidade pós-fogo em espécies lenhosas de campo sujo submetido a três queimadas prescritas anuais. Acta Botanica Brasilica 19: 493-500.

Mews HA, Marimon BS, Maracahipes L, Franczak DD, Marimon-Junior BH. 2011. Dinâmica da comunidade lenhosa de um Cerrado Típico na região Nordeste do Estado de Mato Grosso. Biota Neotropica 11: 73-82. 


\section{Does fire determine distinct floristic composition of two Cerrado savanna communities on different substrates?}

Mews HA, Pinto JRR, Eisenlohr P V, Lenza E. 2014. Does size matter? Conservation implications of differing woody population sizes with equivalent occurrence and diversity of species for threatened savanna habitats. Biodiversity and Conservation 23: 1119-1131.

Mews HA, Silvério DV, Lenza E, Marimon BS. 2013. Influência de agrupamentos de bambu na dinâmica pós-fogo da vegetação lenhosa de um cerrado típico, Mato Grosso, Brasil. Rodriguésia 64: 211-221.

Miranda A, Miranda; H, Dias I, Dias B. 1993. Soil and air temperatures during prescribed fires in Central Brazil. Journal of Tropical Ecology 9: 313-320.

Miranda H, Bustamante M, Miranda A. 2002.The fire factor. In: Oliveira P, Marquis R. (eds.) The cerrados of Brazil: Ecology and natural history of a Neotropical savanna. New York, The University of Columbia Press. p. 51-68.

Moreira AG. 2000. Effects of fire protection on savanna structure in Central Brazil. Journal of Biogeography 27: 1021-1029.

Oliveira-Filho A, Martins. F. 1986. Distribuição, caracterização e composição florística das formações vegetais da região da Salgadeira, na Chapada do Guimarães (MT). Revista Brasileira de Botanica 9: 207-223.

Oliveira-Filho, AT, Ratter, JA. 2002. Vegetation physiognomies and woody flora of the Cerrado biome. In: Oliveira PS, Marquis RJ. (eds.) The Cerrados of Brazil: ecology and natural history of a neotropical savanna. New York, Columbia University Press. p. 91-120.

Pivello V. 2006. Fire managemente for biological conservation in the Brasilian Cerrado. In: Mistry J, Berardi A. (eds.) Savanas and dry forests - Linking people with nature. Ashgate, Hants. p. 129-154.

Pivello VR. 2011. The use of fire in the Cerrado and Amazonian rainforests of Brazil: Past and present. Fire Ecology 7: 24-39.

Pivello V, Norton G. 1996. Firetool: an expert system for the use of prescribed fires in Brazilian savannas. Journal of Applied Ecology 33: 348-356.

Ramos-Neto MB, Pivello VR. 2000. Lightning Fires in a Brazilian Savanna National Park : Rethinking Management Strategies. Environmental Management 26: 675-684.
Reatto A, Correia JR, Spera ST. 2008. Solos do Bioma do Cerrado: aspectos pedológicos. In: Sano SM, Almeida SP, Ribeiro JF. (eds.) Cerrado: ecologia e flora. Planaltina, Embrapa-CPAC. p. 107-149.

Ribeiro JF, Walter BMT. 2008. As principais fitofisionomias do bioma Cerrado. In: Sano SM, Almeida SP, Ribeiro JF. (eds.) Cerrado: ecologia e flora. Planaltina, Embrapa-CPAC. p. 151-212.

Ribeiro MN, Sanchez M, Pedroni F, Peixoto KS. 2012. Fogo e dinâmica da comunidade lenhosa em cerrado sentido restrito, Barra do Garças, Mato Grosso. Acta Botanica Brasilica 26: 203-217.

Ruggiero PGC, Batalha MA, Pivello VR, Meirelles ST. 2002. Soil-vegetation relationships in cerrado (Brazilian savanna) and semideciduous forest, Southeastern Brazil. Plant Ecology 160: 1-16.

Sano EE, Rosa R, Brito JLS, Ferreira LG. 2010. Land cover mapping of the tropical savanna region in Brazil. Environmental Monitoring and Assessment 166: 113-124.

Sato M, Miranda H. 1996. Mortalidade de plantas lenhosas do cerrado sensu stricto submetidas a diferentes regimes de queima. In: Miranda H, Saito C, Dias B. (eds.) Impactos de queimadas em áreas de cerrado e restinga. Brasília, Universidade de Brasília. p. 102-111.

Silva FAM, Assad ED, Evangelista BA. 2008. Caracterização Climática do Bioma Cerrado. In: Sano SM, Almeida SP, Ribeiro JF. (eds.) Cerrado: ecologia e flora. Planaltina, Embrapa-CPAC. p. 67-88.

Silva G, Sato M, Miranda H. 1996. Mortalidade de plantas lenhosas em um campo sujo de cerrado submetido a queimadas prescritas. In: Miranda H, Saito C, Dias B. (eds.) Impactos de queimadas em áreas de cerrado e restinga. Brasília, Universidade de Brasília. p. 93-101.

Tóthmérész B. 1995. Comparison of different methods for diversity ordering. Journal of Vegetation Science 6: 283-290.

Young MD, Solbrig OT. 1993. Economic and ecological driving forces affecting tropical savannas. In: Young MD, Solbrig OT. (eds.) The world's savannas: economic driving forces, ecological constraints and policy options for sustainable land use. New York, Parthenon Publishing. p. 3-18. 